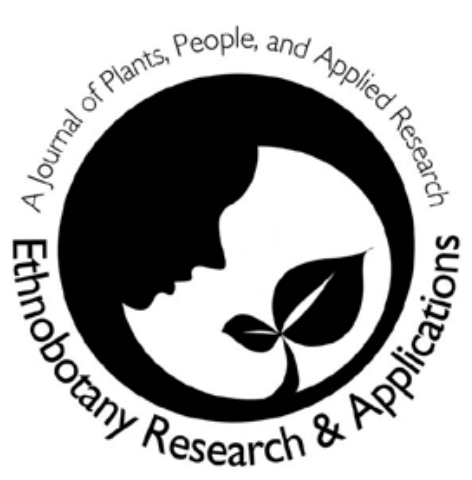

\title{
Strategies for Sustainable Supply of and Trade in Threatened Medicinal Tree Species: A case study of genus Warburgia
}

\author{
Stepha McMullin, Maarten Nieuwenhuis, \\ and Ramni Jamnadass
}

\section{Research}

\begin{abstract}
The use of medicinal tree, shrub, and plant products as a health resource is long-established on the continent of Africa. The continued reliance on such medicinal material and the dominance of its collection from natural populations of species has implications for sustainable use. For many species there is a lack of research on the trade of medicinal material and especially species-specific data relating to the population, distribution, uses, market prospects, and potential for cultivation. The genus Warburgia Engl. includes four tree species found throughout eastern and southern Africa that are used for their medicinal properties to treat numerous human and livestock diseases. This study was undertaken to assess the supply chain for Warburgia in Kenya through market surveys using questionnaires in the three most populous cities: Nairobi, Kisu$\mathrm{mu}$, and Mombasa. Findings from this study indicate that the supply of Warburgia has declined in the last two years and that traders engage in unsustainable practices for addressing supply deficits. These include substitution of species or sourcing species material from different geographical locations. Such strategies can have implications for human and land health. Regional movement of Warburgia for trade is occurring, as it is sourced in Tanzania for trade in Kenyan urban markets. This movement of material indicates a high demand for Warburgia and implies extraneous pressure on available natural resources. The reliance and use of the bark and roots in the markets is a further threat to the use, and alternative, less destructive harvesting strategies should be developed.
\end{abstract}

\section{Introduction}

The genus Warburgia Engl. (Canellaceae) includes four species, W. salutaris (G.Bertol.) Chiov. found in southern Africa, W. elongata Verdc. and W. stuhlmannii Engl. found along the East African coastline, and W. ugandensis Sprague found in the eastern Africa highlands (Muchugi et al. 2008). Warburgia has a native range in the Democratic Republic of Congo, Ethiopia, Kenya, Tanzania, Uganda, Malawi, Mozambique, South Africa, and Swaziland. These species are widely used in Traditional Herbal Medicine (THM), and tree products are prepared and dispensed by traditional health practitioners and herbalists or through self-treatment by patients throughout eastern and southern Africa (Mbwambo et al. 2009). The efficacy of extracts is linked to their antibacterial and antifungal activities, which have been scientifically supported in several trials (Muchugi et al. 2008). There are many variations in the parts used and manner of consumption as a remedy for stomachache, constipation, toothaches, fever, muscle pains, weak joints, and general body pains and to treat malaria (World Agroforestry Centre 2011).

Due to the medicinal properties of Warburgia and other tree and shrub species, a number of species throughout Africa are becoming increasingly threatened. This

\section{Correspondence}

Stepha McMullin and Ramni Jamnadass, World Agroforestry Centre, Nairobi, KENYA. s.mcmullin@cgiar.org

Maarten Nieuwenhuis, UCD Forestry, University College Dublin, IRELAND.
}

Ethnobotany Research \& Applications 12:671-683 (2014)

Published: 18 December 2014 
is due to a rise in trade activities to meet continued demand. The demand and commercial trade of high value products sourced from natural populations (bush, savannah, forest) drives a process of intensified production and specialization by the actors involved in the supply chain (Ruiz-Perez et al. 2004). Trade of medicinal species is growing in Kenya; a study by Muriuki et al. (2012) showed that trade growth in the more formal sector (enterprises and processed medicinal products) was above $10 \%$ per year for specific species such as Warburgia, and material was mainly sourced from natural populations. The use and trade of medicinal material is no longer confined to traditional healers but has entered both the informal and increasingly formal commercial sectors (Dold \& Cocks 2002). This has resulted in an increase in the number of actors involved in supply chain activities, including collectors who harvest material direct from wild populations and traders who engage in marketing and often collection activities (Dold \& Cocks 2002). The intensified collection and trade activities are known to increase the difficulty of managing wild-harvested populations sustainably (Botha et al. 2004b). Demand for material generates species-specific trade networks (Cunningham 1997), which can extend across national boundaries (Dold \& Cocks 2002, Kariuki \& Kibet 2007). For example, South Africa is an important exporter of medicinal material to other southern African countries such as Namibia, Botswana, Mozambique, Zimbabwe, and Malawi. In South Africa, $W$. salutaris has been documented as over-exploited and threatened since the early 1990s (Cunningham 1993). Unsustainable exploitation of medicinal species for commercial trading purposes involves the harvesting of tree and shrub parts, mainly the roots and bark, which is most destructive (Mander 1998). Such harvesting activity has also resulted in notable destruction of medicinal species in their natural habitats (Muchugi et al. 2008). As a result of continued harvesting, several medicinal species have become rare in their natural environment and some have made it onto the Red List of Threatened Species of the International Union for Conservation of Nature (IUCN) (Hawkins 2008). Indeed, W. elongata and $W$. salutaris are listed as endangered and W. stuhlmannii as vulnerable by the IUCN Red List.

In Kenya, Warburgia has become a priority species for research and conservation efforts by the Kenya Forestry Research Institute (KEFRI) and the World Agroforestry Centre (ICRAF). Populations of this species in Kenya are increasingly threatened due to medicinal value and use. Species in this genus in southern Africa are known to be under threat, while in Tanzania, $W$. ugandensis subsp. longifolia Verdc., endemic to the Rondo Plateau, is cited as "vulnerable" on the IUCN Red List. This assessment is in need of updating for all species in this genus.

Concerns for the sustainability of use and the conservation of biodiversity have led to work in South Africa to thoroughly document the trade and supply of $W$. salutaris. This has been to establish the extent of its trade and the impact of harvesting and other disturbances and to develop effective management strategies for in situ and ex situ cultivation (Botha et al. 2004b). Evidence suggests that informal markets for medicinal material are disorganized, with varying constraints impeding sustainable use and adequate economic returns (Botha et al. 2004a, Mander et al. 2007, Williams et al. 2007). In Kenya, trade and market information is very limited, and very little has been done to establish the extent of the trade and the supply chains for priority medicinal tree species. However, in very recent years some research has been published on the subject by McMullin et al. (2012), Muriuki et al. (2012), and Njoroge (2012). This study was conducted to identify the market, trade characteristics, and supply chain for Warburgia in Kenya. The specific objectives of the study were to (i) identify the supply and demand for Warburgia and present a supply chain and (ii) determine the volume of trade and assess an economic value of the trade.

\section{Materials and Methods}

\section{Study area}

The study sites chosen for this research represent the three largest cities in Kenya (Figure 1). Nairobi has a population of 3.1 million and a density of 4515 people per $\mathrm{km}^{2}$. Mombasa, the second largest city, has 968,909 inhabitants and a density of 4292 people per $\mathrm{km}^{2}$. Kisumu has a population of 939,370 and a density of only 465 people per $\mathrm{km}^{2}$. At the country level, $68 \%$ of the population is rural and $32 \%$ are urban dwellers (Kenya National Bureau of Statistics 2010). Geographically, Nairobi is located in the Central Province of Kenya, at an altitude of 1670 masl. Kisumu is located in Nyanza Province and is situated on the shores of Lake Victoria at an altitude of 1160 masl. Mombasa is located in eastern Kenya in the Coast Province on the Indian Ocean coastline and is the main port servicing East Africa. The demand for and potential use of medicinal material are reflected in the cultural and traditional practices of many of the 44 ethnic groups in Kenya, who also have unequal access to medical health facilities (Sindiga et al. 1995). The average ratio of population to medical doctor for the country is $25,000: 1$; for Nairobi it is 23,000:1, Kisumu 15,000:1, and Mombasa 7,000:1 (CRA 2011).

\section{Data collection}

The data collected on the trade of Warburgia were part of a broader study which was conducted to identify the trade and markets of key medicinal tree and shrub species utilized in urban centers in Kenya (McMullin et al. 2012). The data were collected in the period June 2009 to October 2009 across the three most populous urban centers in Kenya: Nairobi, Kisumu, and Mombasa. Data were collected on the most frequently traded medicinal tree species as identified by traders in open-air markets to capture the di- 


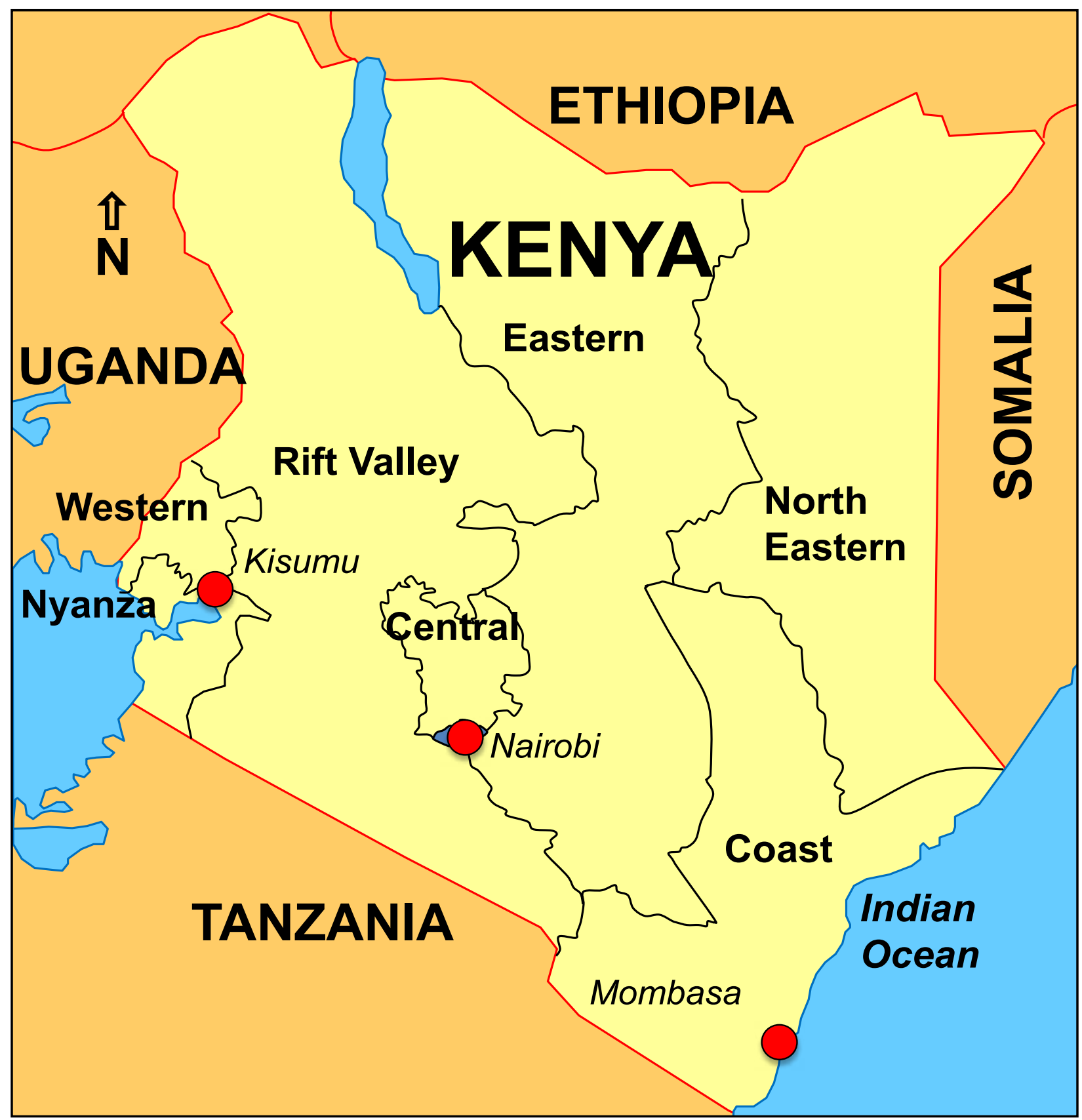

Figure 1. Kenya provinces (Central, Coast, Eastern, Nairobi, North Eastern, Nyanza, Rift Valley, and Western) with city study sites in Kisumu, Nairobi, and Mombasa.

versity and extent of species utilized in the trade. In order to ensure a complete data set on one species, questions on Warburgia were included and posed to all respondents.

Market sites were identified in each city through prior local knowledge. In each city, 11 markets were visited, and a varying number of interviews with traders were conducted at each site, ranging between 23 and 33 interviews (Table 1$)$. The total number of market participants involved in the medicinal material trade-traders, street hawkers, collectors, and herbalists-is unknown and has not been previously estimated or documented in Kenya. As a result, non-probability purposive sampling, using aspects of snowball sampling (Denscombe 2003, May 2001), was used to sample the intended respondent population. Market traders of medicinal material from trees and shrubs were identified as the key stakeholders of this trade who could contribute to meet the research objectives. Trad- 
Table 1. Relationship between socio-economic characteristics of traders and location in study sites in Kisumu, Nairobi, and Mombasa, Kenya.

\begin{tabular}{|c|c|c|c|c|c|}
\hline \multirow[t]{2}{*}{ Variables } & \multicolumn{4}{|c|}{ Site Data } & \multirow{2}{*}{$\begin{array}{l}\text { F/t-value } \\
*=1 \% \\
\text { significance } \\
\text { level }\end{array}$} \\
\hline & Total & Nairobi & Kisumu & Mombasa & \\
\hline \multicolumn{6}{|c|}{ Sample population and size } \\
\hline Study sites & $\mathrm{n}=33$ & $\mathrm{n}=11$ & $\mathrm{n}=11$ & $\mathrm{n}=11$ & \\
\hline Respondents & $\mathrm{n}=91$ & $n=33$ & $\mathrm{n}=35$ & $n=23$ & \\
\hline Warburgia & $\mathrm{n}=84$ & $\mathrm{n}=33$ & $\mathrm{n}=35$ & $\mathrm{n}=16$ & \\
\hline \multicolumn{6}{|l|}{ Gender } \\
\hline Female & $38.5 \%$ & $24.2 \%$ & $60 \%$ & $26.1 \%$ & \multirow[t]{2}{*}{ *11.6 } \\
\hline Male & $61.5 \%$ & $75.8 \%$ & $40 \%$ & $73.9 \%$ & \\
\hline \multicolumn{6}{|l|}{ Age group (years) } \\
\hline Under 35 & $35.4 \%$ & $48.1 \%$ & $18.1 \%$ & $45 \%$ & \multirow[t]{4}{*}{${ }^{*} 7.85$} \\
\hline $35-55$ & $39.2 \%$ & $40.7 \%$ & $31.3 \%$ & $50 \%$ & \\
\hline Over 56 & $25.3 \%$ & $11.1 \%$ & $50 \%$ & $5 \%$ & \\
\hline Average age & 44.6 & 38.3 & 52.8 & 40.1 & \\
\hline \multicolumn{6}{|l|}{ Experience (years) } \\
\hline Less than 10 & $50 \%$ & $53.1 \%$ & $45.7 \%$ & $52.2 \%$ & \\
\hline $11-20$ & $22.2 \%$ & $25 \%$ & $17.1 \%$ & $26.1 \%$ & \\
\hline $21-30$ & $10 \%$ & $12.5 \%$ & $11.4 \%$ & $4.3 \%$ & \\
\hline More than 30 & $17.8 \%$ & $9.4 \%$ & $25.7 \%$ & $17.4 \%$ & \\
\hline Average years & 16.5 & 13.4 & 19.6 & 16.4 & \\
\hline \multicolumn{6}{|l|}{ Income (KSh) } \\
\hline$<1,000$ & $35.2 \%$ & $12.9 \%$ & $52.9 \%$ & $39.1 \%$ & \multirow[t]{5}{*}{ *4.40 } \\
\hline $1,100-2,200$ & $11.4 \%$ & $16.1 \%$ & $11.8 \%$ & $4.3 \%$ & \\
\hline $2,300-3,400$ & $18.2 \%$ & $35.5 \%$ & $11.8 \%$ & $4.3 \%$ & \\
\hline$>3,500$ & $33 \%$ & $32.3 \%$ & $23.5 \%$ & $47.8 \%$ & \\
\hline Would not disclose & $2.3 \%$ & $3.2 \%$ & 0 & $4.3 \%$ & \\
\hline \multicolumn{6}{|l|}{ Additional IGA } \\
\hline Yes & $39.6 \%$ & $60.6 \%$ & $20 \%$ & $39.1 \%$ & \multirow[t]{2}{*}{ *11.71 } \\
\hline No & $60.4 \%$ & $39.4 \%$ & $80 \%$ & $60.9 \%$ & \\
\hline \multicolumn{6}{|l|}{ Land ownership } \\
\hline Yes & $92.3 \%$ & $97.0 \%$ & $97.1 \%$ & $78.3 \%$ & \\
\hline No & $7.7 \%$ & $3 \%$ & $2.9 \%$ & $21.7 \%$ & \\
\hline
\end{tabular}

ers could be identified visually by their trade (Figure 2), whereas collectors are often elusive and infrequent visitors to the markets and street hawkers are often mobile and not fixed to any specific location. A similar challenge has been encountered in market studies in South Africa (Botha et al. 2004a).

\section{Market interviews}

Semi-structured interviews were used to collect data from respondents. The design of the questionnaire used dur- ing the interviews required the incorporation of key market questions, with the necessary flexibility to deal with the largely informal nature of the trade. Specific questions were asked to collect data on the socio-demographics of the traders, the supply in terms of species, parts used, source, availability, and demand issues such as seasonality, consumer preference, and pricing information. For pricing units the following currency conversion was used: 100 Kenyan Shillings $(\mathrm{KSh})=1.20 \mathrm{USD},=0.82$ Euro (XE 2011). Vernacular names as stated by interviewees were used during the study and verified using Dharani 


\section{McMullin et al. - Strategies for Sustainable Supply of and Trade in Threatened Medicinal Tree Species: A case study of genus Warburgia}
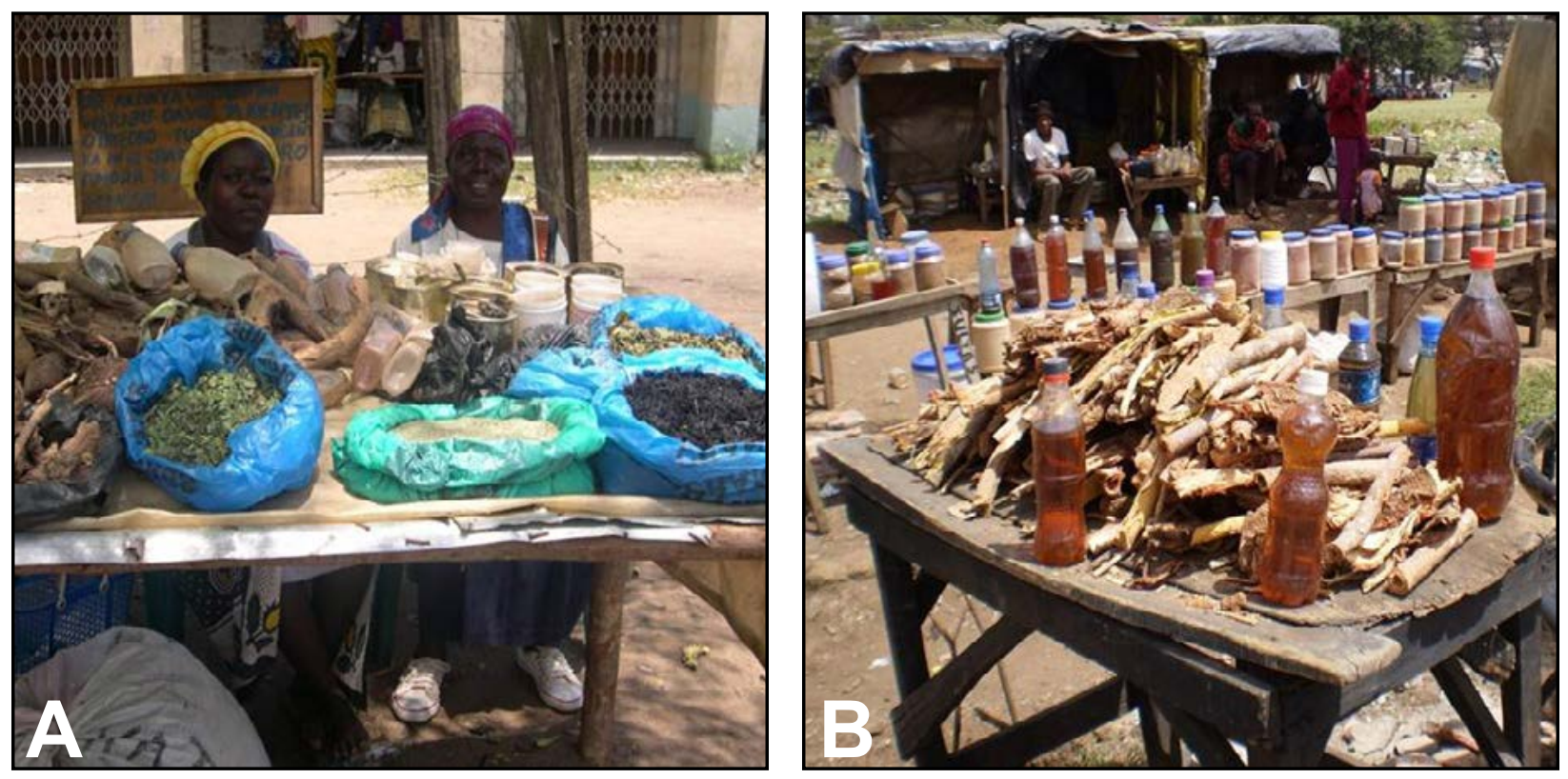

Figure 2. Medicinal market stalls in Kisumu (A) and Nairobi (B), Kenya.

(2002), Kariuki \& Kibet (2007), Kokwaro (2009), Maundu \& Tengnas (2005), and Sindiga et al. (1995). Further confirmation of species was through visual identification by the research team with prior experience undertaking ethnobotanical studies in Kenya (through the National Museums of Kenya). To avoid potential breach of intellectual property or the perception that local knowledge was being used for purposes other than to contribute to knowledge on the subject matter, species used in complex combinations with Warburgia for specific treatments were not recorded. The data collected on the trade in this study are reflective of the seasons in which fieldwork was conducted; these were the "summer June long-dry" and the "autumn October rains" seasons.

\section{Data analysis techniques}

The quantitative data collected in the market interviews were initially entered into Microsoft Excel, where data were re-coded, sorted, and structured for the purpose of exportation to SPSS (Statistical Package for the Social Sciences, SPSS Statistics for Windows Version 19.0). Analysis was descriptive and quantitative, utilizing frequency, mean, standard deviation, and statistical comparisons, with the use of the T-test and analysis of variance (ANOVA). Variables analyzed included the traders' gender, age, length of time engaged in the trade, location, and income generated from the trade. Initial analysis of the qualitative data occurred during the data collection process, when preliminary coding, organization, and evaluation of such data were used to inform additional data collection through discussion points.

\section{Results}

\section{Socio-demographics of traders}

Sixty-one percent of all traders were male. The proportion of female traders differed significantly between the locations. About three-quarters of traders in Nairobi and Mombasa were male, while in Kisumu $60 \%$ were female (Table 1). The average age of traders across locations was 45 years. Kisumu had a significantly higher proportion of traders in the older age group (over 56 years) than Nairobi, where the under-35 years age group dominated, and in Mombasa, where $50 \%$ of respondents were in the $35-55$ years age group (Table 1 ).

Sixty percent of all respondents indicated that the income earned from the trade was the sole income-generating activity (IGA) for their household (Table 1). Additional IGAs were more common among traders in Nairobi than in Mombasa or Kisumu (Table 1). Livestock keeping, crop farming, craftwork, and night guard duties were listed as additional income-generating activities by respondents. Thirty-five percent of the traders cited an income of less than KSh 1000 per week from this trade, while 33\% cited earning more than KSh 3500 per week (Table 1). A statistically significant difference in average income earned from the trade was observed, with a lower income in Kisumu $(F(2,85)=4.40, p=0.01)$ than in the other two cities. There was no significant difference in the average weekly income earned between male and female traders $(t(86)=-1.41, p=0.256)$. To investigate the link between the urban trade of medicinal material and rural locations and subsistence land use, respondents were asked about land ownership. Ninety-two percent of respondents inter- 
viewed owned a piece of land; this was lowest in Mombasa (Table 1).

\section{Tree parts traded and used to treat health conditions}

Of the 91 traders interviewed for the purpose of this study, 84 were trading in Warburgia. This taxa was used most commonly in combination with other species to treat chest and stomach conditions, malaria, typhoid, and other wa- ter-borne conditions (Figure 3 ). In this study, lack of distinction between diseases and symptoms of disease were noted during data collection from herbalists and traders. This is due to local disease nomenclature based on symptoms of disease and not according to etiological information (Nanyingi et al. 2008). The parts used most commonly in the preparation of treatments for health conditions and traded in the markets are bark and roots; traders in Nairobi indicated exclusive use of bark (Figure 4).
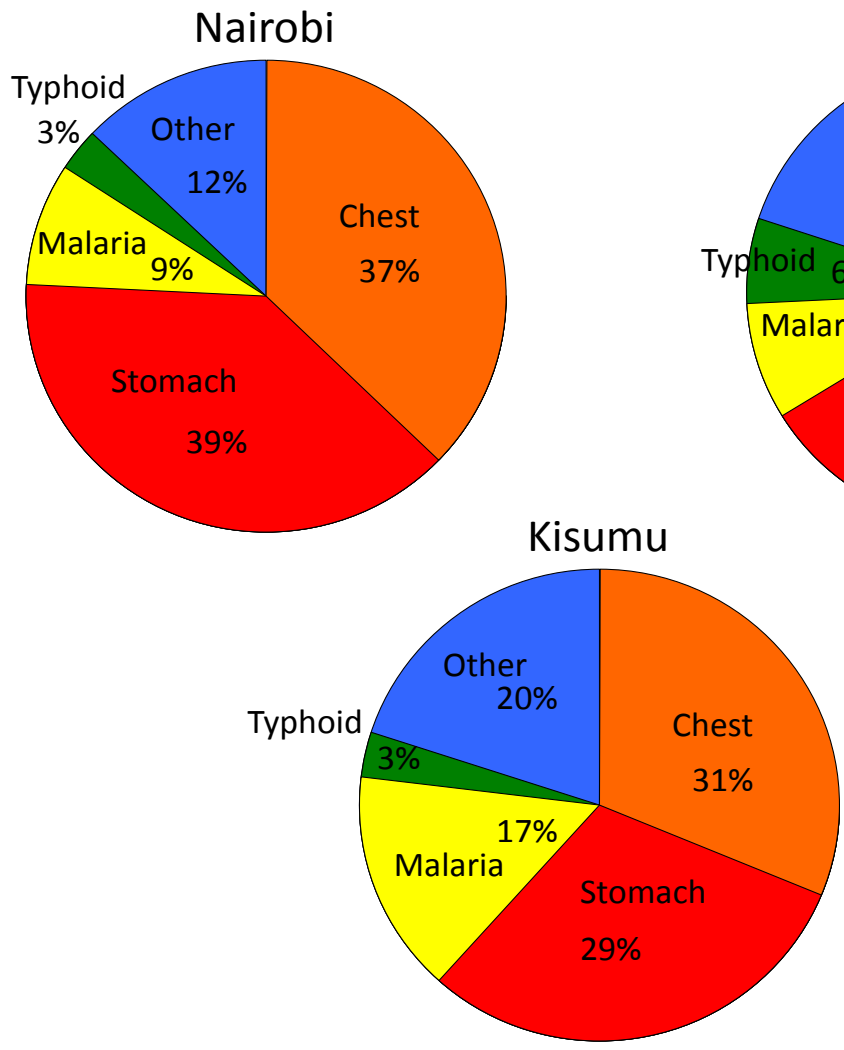

Mombasa

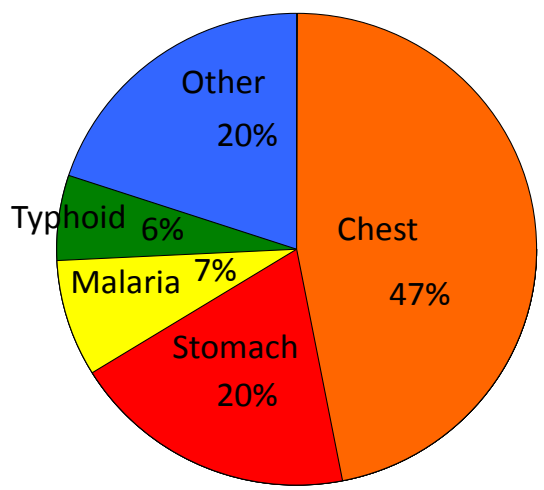

Three city total

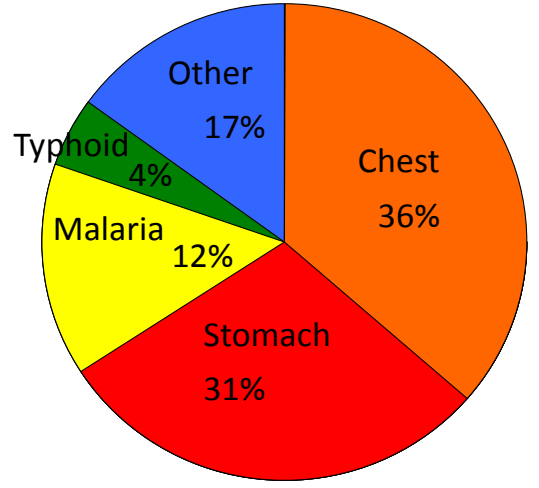

Figure 3. Most common health conditions treated with Warburgia in Nairobi, Kisumu, and Mombasa, Kenya.

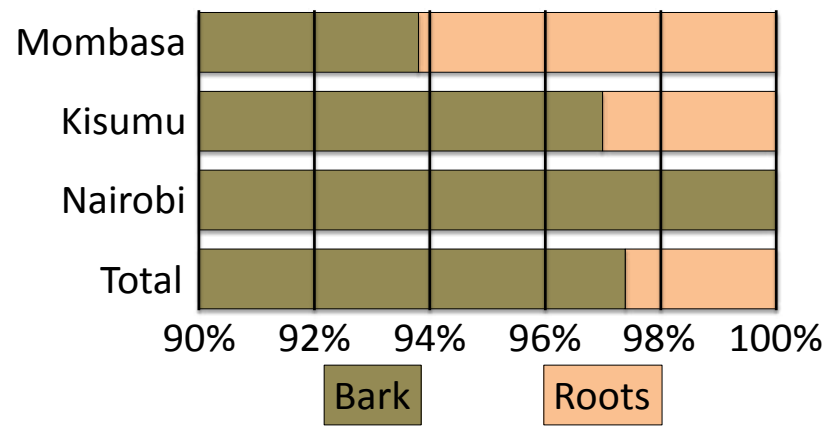

Figure 4. Most common Warburgia parts used and traded in the markets of Nairobi, Kisumu, and Mombasa, Kenya.

\section{Source of Warburgia and stocking activity}

Six locations were identified as the main source for Warburgia; these included five provinces and Tanzania (Figures 1 and 5). Locations identified in Tanzania included Kilimanjaro, Arusha, Morogoro, and Serengeti, all in proximity to the Kenyan border. Nineteen percent of Warburgia in the markets in Mombasa was said to be sourced from Tanzania; this was $11 \%$ in Nairobi but none in Kisumu. Within the six locations, 33 district locations were identified, indicating the large geographical range of the species and harvesting locales.

Stocking activities for Warburgia included direct collection by traders from the wild/natural populations of the species 

Threatened Medicinal Tree Species: A case study of genus Warburgia

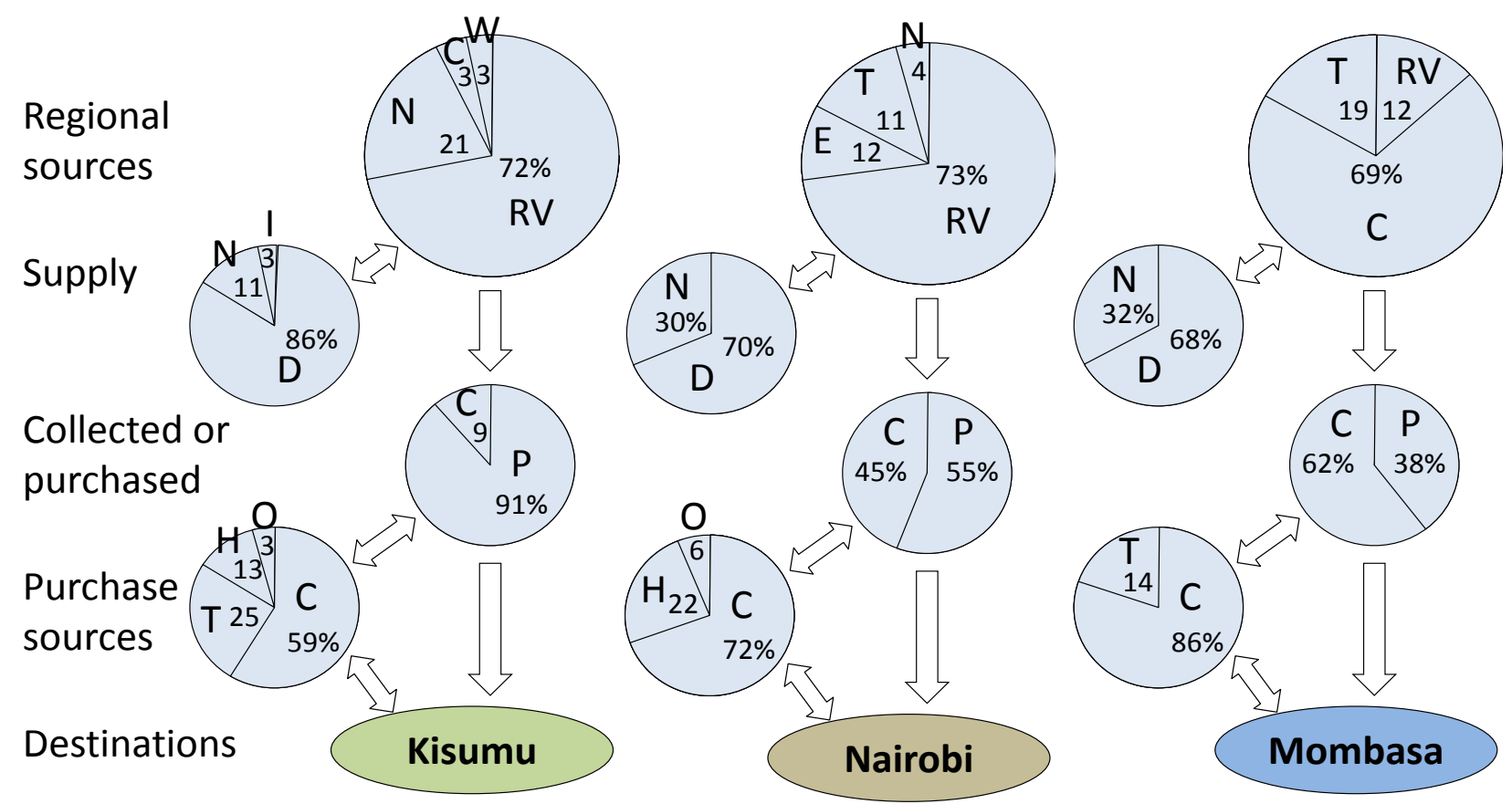

Figure 5. Supply chains for Warburgia to the three major cities in Kenya: Kisumu, Nairobi, and Mombasa. Supply assessment: I - increased, D - decreased, N - no change. Regional sources: RV - Rift Valley, N - Nyanza, W - Western, C - Coast, E - Eastern, T - Tanzania. Purchase sources: $\mathbf{T}=$ other trader, $\mathbf{H}$ - herbalist, $\mathbf{C}$ - collector, $\mathbf{O}$ - other.

or the (wholesale) purchase of stock from sources such as other traders, collectors, and herbalists (middlemen). In Nairobi, the percentages of traders involved in direct collection or purchasing of stock were similar (45\% and 55\%, respectively). However, in Kisumu, the (wholesale) purchasing of Warburgia (91\%) dominated the stocking activities carried out by traders, whereas in Mombasa, direct collection of tree material by traders (62\%) was most common (Figure 5).

A larger percentage of traders in Kisumu (86\%) noted a decrease in supply (availability) for the previous two years (2007-2008) than in Nairobi $(70 \%)$ or Mombasa $(68 \%)$ (Figure 5). Depending on the activity used to stock material, traders provided varying explanations for the supply trends. For traders that were involved in the collection of material from the wild, "weather variability" (35\%) and "over-harvesting"' (25\%) were most commonly cited as the reason for decreased supply trends (Figure 6). Traders involved in the (wholesale) purchasing of material for trade in markets noted that "overharvesting" (32\%) and "restricted access to land" (25\%)

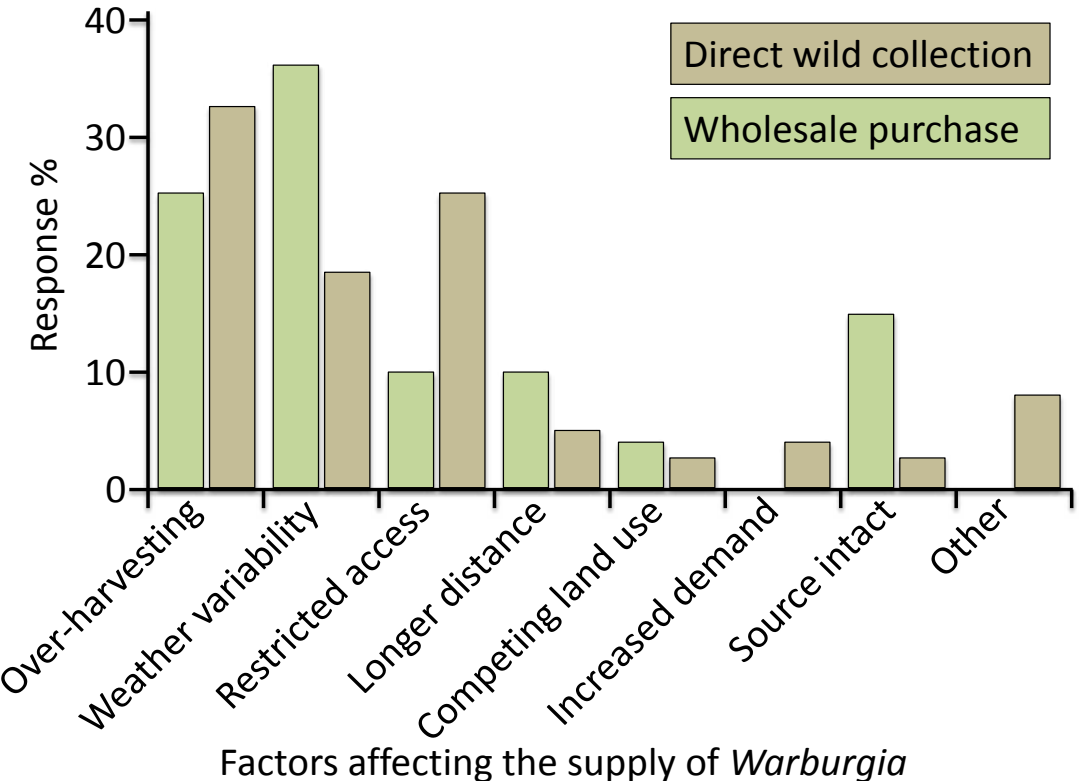

Figure 6. Factors affecting the supply of Warburgia based on stock activity (direct collection from the wild or wholesale purchase) in Kenya.

were the reasons that affected supply of Warburgia to the urban markets (Figure 6). As the supply of Warburgia has decreased in the last two years, described both as "low" and "slow," traders have developed a number of alternative strategies to address the supply deficit (Figure 7). Traders who directly collect material from the wild mostly 


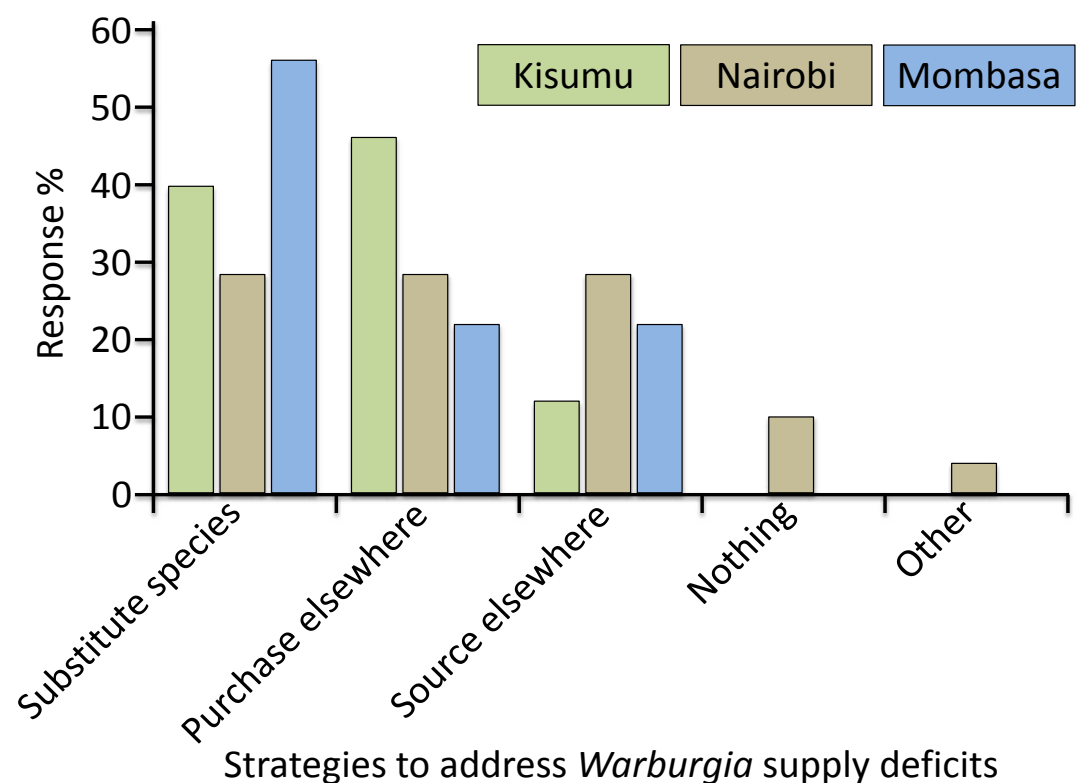

Figure 7. Strategies used by traders to address Warburgia supply deficits in Kisumu, Nairobi, and Mombasa, Kenya.

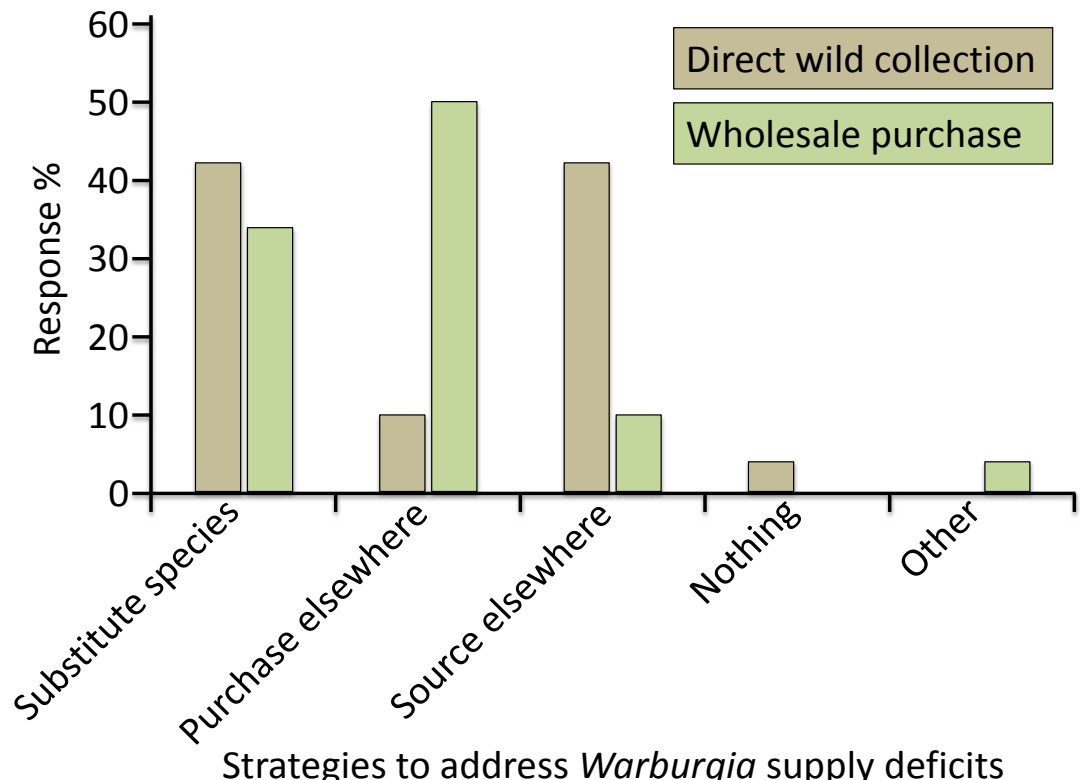

Figure 8. Strategies used by traders to address Warburgia supply deficits, based on stock activity (direct collection from the wild or wholesale purchase) in Kenya.

address supply deficits by substituting Warburgia with another species or sourcing elsewhere; this includes different known geographical collection areas and locales not previously used for collection activities (Figure 8).

Fifty-nine percent of all traders stated that the general supply of medicinal material was not meeting current market demand, while $41 \%$ indicated current supply was meeting the demand. In Nairobi, supply met current demand according to $53 \%$ of traders, while in Mombasa and Kisumu a supply deficit was identified by $57 \%$ and $71 \%$ of traders, respectively. Supply issues identified by traders were "slow supply" (29\%), "difficulty sourcing from wild" (23\%), and "increasing demand" $(23 \%)$. However, $23 \%$ of traders expressed no concern for supply not meeting demand and insisted material can always be sourced from somewhere.

\section{Quantities and pricing of Warburgia sourced, stocked, and traded in the urban markets}

The quantities of Warburgia stocked by traders were similar to those of other medicinal species, with no statistically significant differences in the quantities stocked, traded, or dispensed per transaction (Table 2). However, there was a significant difference in quantities of material stocked based on stocking activity (direct collection from the wild versus wholesale purchase), with larger quantities stocked if collected $(t$ $(71)=-2.37, p=0.02$ ) rather than purchased. There was no significant difference between quantities sold to customers based on stocking activities. This is in contrast to analysis conducted for all other species on which data were collected, where a significant difference (t (159), = -2.40, $p=0.01$ ) was found, with larger quantities of material traded if based on direct collection from the wild by the traders.

The purchase price for this species was similar to those for other species on which data were collected in the wider study. The average wholesale purchase cost for material was KSh 1090 ( \pm 1426$)$. This refers to the purchase price traders pay for material from collectors. There was a statistically significant difference in the wholesale purchase prices paid by male and female traders (Table 2). The average customer transaction price for Warburgia material is KSh 121 ( \pm 140$)$.

The high variation in prices for medicinal material between collectors, traders, herbalists, and consumers is a characteristic of the informal nature of the trade, which is dominated by casual negotiation and culturally bound 


\section{McMullin et al. - Strategies for Sustainable Supply of and Trade in Threatened Medicinal Tree Species: A case study of genus Warburgia}

Table 2. Average quantity of Warburgia stocked, traded, and dispensed and average pricing and value of Warburgia in relation to other medicinal tree and shrub species traded, by location and gender or traders in three major cities in Kenya: Nairobi, Kisumu, and Mombasa. *Due to the variation in frequency of stocking and quantities stocked, data were collected for the quantity stocked and then based on the frequency of stocking indicated by the trader (e.g., weekly, monthly). This figure was then calculated to identify the average quantities of material stocked on a weekly basis. Total quantity stocked denotes the quantity of material stocked at any one time (this specifically refers to the quantity stocked prior to the interview).

\begin{tabular}{|c|c|c|c|c|c|c|c|}
\hline & \multicolumn{4}{|c|}{ Volume (Mean / SD) } & \multicolumn{3}{|c|}{ Kenyan Shillings (Mean / SD) } \\
\hline & $\begin{array}{l}\text { Quantity } \\
\text { stocked* }^{*} \\
(\mathrm{~kg})\end{array}$ & $\begin{array}{l}\text { Quantity } \\
\text { stocked } \\
\text { weekly (kg) }\end{array}$ & $\begin{array}{l}\text { Quantity } \\
\text { traded } \\
\text { weekly }(\mathrm{kg})\end{array}$ & $\begin{array}{l}\text { Quantity } \\
\text { dispensed } \\
\text { per } \\
\text { transaction } \\
\text { (g) }\end{array}$ & $\begin{array}{l}\text { Avg. } \\
\text { wholesale } \\
\text { purchase } \\
\text { price for } \\
\text { stock }\end{array}$ & $\begin{array}{l}\text { Avg. } \\
\text { price per } \\
\text { transaction }\end{array}$ & $\begin{array}{l}\text { Price } \\
\text { per } 5 \mathrm{~g}\end{array}$ \\
\hline Warburgia & $\begin{array}{l}12.95 / \\
24.44\end{array}$ & $3.19 / 7.05$ & $1.39 / 2.06$ & $\begin{array}{l}30.07 / \\
117.36\end{array}$ & $\begin{array}{l}1090.0 / \\
1426.2\end{array}$ & $\begin{array}{l}121.3 / \\
139.9\end{array}$ & $65.0 / 97.4$ \\
\hline $\begin{array}{l}\text { Other medicinal } \\
\text { species traded }\end{array}$ & $\begin{array}{l}14.01 / \\
22.84\end{array}$ & $5.50 / 13.19$ & $3.44 / 9.74$ & $\begin{array}{l}34.68 / \\
61.24\end{array}$ & $\begin{array}{l}1020.2 \text { I } \\
1574.1\end{array}$ & $\begin{array}{l}169.7 / \\
240.1\end{array}$ & $51.5 / 74.6$ \\
\hline T-test & $\begin{array}{l}T=-0.70 \\
p=0.47\end{array}$ & $\begin{array}{l}T=-1.09 \\
p=0.27\end{array}$ & $\begin{array}{l}T=-1.93 \\
p=0.05\end{array}$ & $\begin{array}{l}T=-1.88 \\
p=0.06\end{array}$ & $\begin{array}{l}T=0.39 \\
p=0.47\end{array}$ & $\begin{array}{l}T=-1.57 \\
p=0.11\end{array}$ & $\begin{array}{l}T=0.71 \\
p=0.47\end{array}$ \\
\hline Nairobi & $\begin{array}{l}10.20 / \\
18.23\end{array}$ & $2.84 / 4.88$ & $1.74 / 2.25$ & $\begin{array}{l}21.50 / \\
24.53\end{array}$ & $\begin{array}{l}1433.3 / \\
1328.4\end{array}$ & $\begin{array}{l}144.6 / \\
166.9\end{array}$ & $67.9 / 111.9$ \\
\hline Kisumu & $\begin{array}{l}17.20 / \\
32.16\end{array}$ & $2.45 / 3.78$ & $1.31 / 2.18$ & $\begin{array}{l}46.85 / \\
190.96\end{array}$ & $\begin{array}{l}842.1 / \\
1299.2\end{array}$ & $79.3 / 103.0$ & $44.4 / 56.8$ \\
\hline Mombasa & $\begin{array}{l}10.25 / \\
17.13\end{array}$ & $5.31 / 13.25$ & $0.87 / 1.29$ & $\begin{array}{l}17.81 / \\
30.38\end{array}$ & $\begin{array}{l}1341.6 / \\
2295.3\end{array}$ & $\begin{array}{l}140.6 / \\
124.9\end{array}$ & $94.5 / 118.6$ \\
\hline ANOVA & $\begin{array}{l}F=2.27 \\
p=0.11\end{array}$ & $\begin{array}{l}F=1.61 \\
p=0.20\end{array}$ & $\begin{array}{l}F=1.11 \\
p=0.33\end{array}$ & $\begin{array}{l}F=0.89 \\
p=0.41\end{array}$ & $\begin{array}{l}F=2.28 \\
p=0.11\end{array}$ & $\begin{array}{l}F=0.85 \\
p=0.43\end{array}$ & $\begin{array}{l}F=1.34 \\
p=0.26\end{array}$ \\
\hline Male trader & $\begin{array}{l}12.40 / \\
23.54\end{array}$ & $2.52 / 4.50$ & $1.36 / 1.88$ & $\begin{array}{l}39.36 / \\
145.60\end{array}$ & $\begin{array}{l}1326.4 / \\
1396.3\end{array}$ & $\begin{array}{l}128.0 / \\
154.2\end{array}$ & $78.5 / 116.1$ \\
\hline Female trader & $\begin{array}{l}13.86 / \\
26.27\end{array}$ & $4.29 / 9.95$ & $1.44 / 2.34$ & $\begin{array}{l}13.27 / \\
14.20\end{array}$ & $\begin{array}{l}845.0 / \\
1461.8\end{array}$ & $\begin{array}{l}109.4 / \\
111.6\end{array}$ & $40.7 / 40.0$ \\
\hline T-test & $\begin{array}{l}T=-0.01 \\
p=0.90\end{array}$ & $\begin{array}{l}T=-0.89 \\
p=0.37\end{array}$ & $\begin{array}{l}T=-0.40 \\
p=0.69\end{array}$ & $\begin{array}{l}T=0.05 \\
p=0.95\end{array}$ & $\begin{array}{l}T=-2.16 \\
p=0.03\end{array}$ & $\begin{array}{l}T=-0.58 \\
p=0.95\end{array}$ & $\begin{array}{l}T=-2.65 \\
p=0.01\end{array}$ \\
\hline
\end{tabular}

transactions. It has implications for the trade as it (i) complicates conducting research and collecting data on volume of material traded and (ii) raises serious concerns for the sustainability of natural resources as the volume of material collected from the wild and traded is widely unknown and is potentially under-estimated.

\section{Discussion}

This study found that for more than half of the respondents interviewed $(60 \%)$ the income earned from the trade was the sole income-generating activity for their household. This indicates the importance of the trade and associated collection activities to the cash resources of these households across the three study locales. A further finding is the disparity in the income generated by traders based on the location of the respondents, with many in Kisumu earning disproportionality less from the trade than their counterparts in Nairobi and Mombasa. In addition, nearly three-quarters of traders in Kisumu were female compared to one-quarter in Nairobi and Mombasa, respectively. These findings raise many interesting questions about the factors which determine the income generated from the trade including the location of the markets, the gender of the traders, the poverty level of trader households, the trade itself in terms of quantities collected and traded, the pricing determined by traders, the significance of negotiation, etc. Due to the informal nature of the trade and the strong cultural use and preference for materials used in traditional medicine, there are most likely important sociocultural factors and relations which determine the transactions along the supply chain and in the trade.

Traders in Kenya identified the predominant use of the bark and roots of Warburgia, with traders in Nairobi exclusively using the bark. The harvesting of bark and roots has been noted as the most destructive use of medicinal species (Mander 1998), particularly when commercial 
harvesting is carried out by non-specialists (Cunningham 1993). And while growth in the trade of medicinals in urban areas of Kenya has been noted, supply shortages are evident (Njoroge 2012). In general, collection from natural populations is a major source of resource depletion of medicinal species, and its impact is largely dependent on the part(s) removed and on the harvesting techniques employed (Williams et al. 2007). The parts used in treatment and the trade delineate the use in terms of ecological sustainability. The heavy reliance and use of bark and roots needs to be addressed to ensure appropriate use and conservation. The two biologically active compounds found in Warburgia, warburganal and polygodial, are present in the roots, bark, and also the leaves (Botha et al. 2004b). However, the findings show that the leaves are not used at all in the trade in Kenya. To address the conservation threat to Warburgia, one option would be to initiate a strategy for sustainable harvesting practices based on the substitution of bark and roots by leaves. It is also essential to document and understand the traditional ecological knowledge and local management techniques of in-demand species, such as Warburgia in specific geographical locales. This is necessary to identify the best management systems for the sustainable growth and use of medicinal species (Baldauf \& Maes dos Santos 2013).

Nineteen percent of Warburgia in the markets in Mombasa were said to be sourced from Tanzania; this was $11 \%$ in Nairobi and none in Kisumu. The regional movement of medicinal material, without proper monitoring and control systems, can have negative repercussions for sustainability and conservation and implies extraneous pressure on natural resources (Krog et al. 2006). Warburgia ugandensis subsp. longifolia in Tanzania has already been identified by the IUCN as vulnerable, and further monitoring of this sub-species in its habitat needs to be undertaken. Furthermore, traders in Kenya address supply deficits by sourcing from wider geographical locales previously unused as source/harvesting spots. From a conservation and sustainable use perspective, Cunningham (1997) identified two categories of medicinal tree and shrub species that have been of concern on an Africa-wide scale. First, where slow-growing species with a limited distribution are the focus of commercial harvesting with demand exceeding supply, wild collection takes place further afield, and widespread depletion occurs with the species becoming endangered regionally. This is the case with $W$. salutaris in southern Africa and has been noted in eastern Africa.

The second category of medicinal species that requires attention for conservation is where a species may be popular but not necessarily endangered due its wide distribution, but where habitat changes through commercial harvesting are cause for concern (Cunningham 1997). A study by Ruiz-Perez et al. (2004) on the harvesting of non-timber forest products (including medicinals) found that in most cases the strategies adopted by harvesters were commercial-oriented, reinforcing the idea that an increase in demand may lead to over-exploitation and/or domestication. The growing commercial trade of medicinal species has resulted in the harvest of increasing volumes from natural populations (Kuipers 1997). The prices paid to collectors of material from the wild/natural populations are often low, and those involved in commercial collection for supply to markets "mine" the natural resources rather than "manage" them, as their main objective is to generate income.

To address issues of sustainable use, there is a need to institute strategies appropriate for those involved in the trade. One such strategy would be to promote the cultivation of medicinal tree and shrub species. Ninety-two percent of respondents in this study indicated the ownership of land; this opens up the opportunity for traders to participate in the supply of species and to support conservation of in-demand species through the domestication and cultivation on smallholder farms. Small-scale tree cultivation and home-gardens require low economic inputs and can be a response to declining local stocks and bolster supply chains. Furthermore, they can provide an additional income-generating opportunity for rural households and communities while supplying national and regional markets (Schippmann et al. 2002). However, to promote the cultivation of medicinal tree and shrub species, it is important to note two concerns. First, commercial cultivation of high priority species is not a straightforward solution as it is not deemed to be a profitable project for most species due to slow growth and low and unpredictable prices paid for material, the latter of which was observed in this study, reflected in the high variation in pricing of material. Cunningham (1993) argued that low prices, whether for local use or international trade, ensure that few species can be marketed at a high enough price to make cultivation profitable. If sufficient volumes of material can be collected from the wild at lower prices, this makes cultivation economically unfeasible, as the cost and time required cannot compete with wild sourcing and lack of input costs incurred by collectors. This is evident from the findings of this study, where the economic value and the volumes of material wild collected and traded varied considerably, most probably due to the extent of collection from the wild rather than cultivated sources and the increased competition between actors involved in the supply chain.

Second, Cunningham (1993) noted that although cultivation can support conservation of species and reduce the extent of collection from natural populations, it may also lead to environmental degradation and loss of genetic diversity, as well as loss of incentives to continue conservation of such populations (Canter et al. 2005; Schippmann et al. 2006). For these reasons and due to scant research in the area of medicinals and compounded by a lack of institutional support for the production and dissemination of key species, the extent of cultivation of medicinal species globally has been limited. This is particularly the case in 


\section{McMullin et al. - Strategies for Sustainable Supply of and Trade in Threatened Medicinal Tree Species: A case study of genus Warburgia}

sub-Saharan Africa. The cultivation of medicinal tree and shrub species is not straightforward, and there is a need for further research to establish the economic and ecological benefits and limitations of cultivation.

A further strategy to address the unsustainable harvesting activities of medicinal trees and shrubs which are demanded in the trade would be to initiate awareness and training campaigns. The main stakeholders and actors involved in the supply chain of medicinal species and parts would benefit from capacity building and awareness for sustainable harvesting techniques and conservation of species. The world over, there are many tree and shrub species which hold valuable active compounds used to treat multiple communicable and non-communicable diseases, some of which are known but many which remain unknown due to lengthy, costly, and limited research investments. Raising awareness about the value and need for sustainable use of medicinals can empower those involved to become custodians of important indigenous knowledge about the identification of species, use, and harvesting techniques to ensure ownership of valuable genetic resources and sustained use. Essentially, medicinal tree and shrub species and the natural resources they are derived from, whether on farm or from the wild, need to be given a value. This requires a system in place whereby harvesting such material incurs a cost to reflect the material's value and the impact of its harvesting on the natural resource base.

\section{Conclusion}

The species-specific trade data for Warburgia collected in this study provide a new insight into a high demand, high priority medicinal tree species in Kenya. The trade in Warburgia and other medicinal species is thriving in Kenya, as evident from the markets in Nairobi, Kisumu, and Mombasa. The "low" and "slow" supply of these species, the strategies used to address supply deficits, and the tree and shrub parts most frequently traded all have implications for conservation and sustainable use. Further research is required to investigate the threat to the natural populations of Warburgia in Kenya and the wider region, and its status needs to be reviewed by international conservation agencies such as the IUCN and the World Conservation and Monitoring Centre. Further research is required to establish (i) the current ecological sustainability of the species and alternative approaches to encourage low impact harvesting of this species and the tree parts used, (ii) the economic and ecological benefits from cultivating it on smallholder farms, and (iii) an awareness for the sustainable use and conservation by the main stakeholders involved.

\section{Acknowledgments}

The authors wish to thank the late Mr. Dennis Osino for his relentless efforts during the fieldwork and data collection and for his trusted ability to develop a rapport with the respondents involved in the study. The authors appreciate the time and knowledge that respondents shared during the data collection process.

\section{Literature Cited}

Baldauf, C. \& F.A Maës dos Santos. 2013. Ethnobotany, traditional knowledge, and diachronic changes in non-timber forest products management: A case study of Himatanthus drasticus (Apocynaceae) in the Brazilian savannah. Economic Botany 67(2):110-120. dx.doi. org/10.1007/s12231-013-9228-5

Botha, J., E.T.F. Witkowski \& C.M. Shackleton. 2004a. Market profiles and trade in medicinal plants in the Lowveld, South Africa. Environmental Conservation 31(1):38-46. dx.doi.org/10.1017/S0376892904001067

Botha, J., E.T.F. Witkowski \& C.M. Shackleton. 2004b. The impact of commercial harvesting on Warburgia salutaris ('pepper-bark tree') in Mpumalanga South Africa. Biodiversity Conservation 13(9):1675-1698. dx.doi. org/10.1023/B:BIOC.0000029333.72945.b0

Canter, P.H., H. Thomas \& E. Ernst. 2005. Bringing medicinal plants into cultivation: Opportunities and challenges for biotechnology. Trends in Biotechnology 23(4):180185. dx.doi.org/10.1016/j.tibtech.2005.02.002

CRA (Commission on Revenue Allocation). 2011. Kenya County Fact Sheets. www.crakenya.org/wp-content/uploads/2013/10/Kenya-County-Fact-Sheets Dec-2011.pdf

Cunningham, A.B. 1993. African Medicinal Plants: Setting priorities at the interface between conservation and primary health care. People and Plants Working Paper 1. People and Plants Initiative, Division of Ecological Sciences, United Nations Educational, Scientific and Cultural Organization (UNESCO), Paris, France.http://unesdoc. unesco.org/images/0009/000967/096707e.pdf

Cunningham, A.B. 1997. An Africa-wide overview of medicinal plant harvesting, conservation and health care. Pp. 116-129 in Medicinal Plants for Forest Conservation and Health Care. Non-Wood Forest Products 11. Edited by G. Bodeker, K.K.S. Bhat, J. Burley \& P. Vantomme. Food and Agriculture Organization of the United Nations, Rome, Italy. www.fao.org/3/a-w7261e.pdf

Cunningham, A.B. \& F.T. Mbenkum. 1993. Sustainability of Harvesting Prunus africana Bark in Cameroon: A medicinal plant in international trade. People and Plants Working Paper 2. People and Plants Initiative, Division of Ecologi- 
cal Sciences, United Nations Educational, Scientific and Cultural Organization (UNESCO), Paris, France. http:// unesdoc.unesco.org/images/0009/000987/098761e.pdf

Denscombe, M. 2003. The Good Research Guide for Small-Scale Social Research Projects. Second Edition. Open University Press, Philadelphia, Pennsylvania, U.S.A.

Dharani, N. 2002. Field Guide to Common Trees and Shrubs of East Africa. Struik Nature, Cape Town, South Africa.

Dold, A.P. \& M.L. Cocks. 2002. The trade in medicinal plants in the Eastern Cape Province, South Africa. South African Journal of Science 98:589-597.

Hawkins, B. 2008. Plants for Life: Medicinal plant conservation and botanic gardens. Botanic Gardens Conservation International, Richmond, Surrey, U.K.

Kariuki, P. \& S. Kibet. 2007. Medicinals Traded in Kenya: Market survey report on Nairobi, Nyanza and Coast regions. Kenya Resource Centre for Indigenous Knowledge (KENRIK), National Museums of Kenya, Nairobi, Kenya.

Kenya National Bureau of Statistics. 2010. www.knbs. or.ke Accessed 31 August 2014.

Kokwaro, J.O. 2009. Medicinal Plants of East Africa. Third Edition. University of Nairobi Press, Nairobi, Kenya.

Krog, M.P., M.P. Falcâo \& C. Smith-Olsen. 2006. Medicinal Plant Markets and Trade in Maputo, Mozambique. Forest \& Landscape Working Papers no. 16-2006. Danish Centre for Forest, Landscape and Planning, KVL., Hørsholm, Denmark.

Kuipers, S.E. 1997. Trade in medicinal plants. Pp. 45-59 in Medicinal Plants for Forest Conservation and Health Care. Non-Wood Forest Products 11. Edited by G. Bodeker, K.K.S. Bhat, J. Burley \& P. Vantomme. Food and Agriculture Organization of the United Nations, Rome, Italy. www.fao.org/3/a-w7261e.pdf

Mander, M. 1998. Marketing of Indigenous Medicinal Plants in South Africa: A case study of Kwazulu-Natal. Food and Agriculture Organization of the United Nations, Rome, Italy. www.fao.org/docrep/019/w9195e/w9195e. pdf

Mander, M., L. Ntuli, N. Diederichs \& K. Mavundla. 2007. Economics of the traditional medicine trade in South Africa. South African Health Review 12:189-196. www.hst. org.za/uploads/files/chap13 07.pdf

Maundu, P.M. \& B. Tengnäs. 2005. Useful Trees and Shrubs of Kenya. Technical handbook No.35. World Agro- forestry Centre, Eastern and Central Africa Regional Programme, Nairobi, Kenya.

May, T. 2001. Social Research Issues, Methods \& Processes. Third Edition. Open University Press, Philadelphia, Pennsylvania, U.S.A.

Mbwambo, Z.H., P. Erasto, E. Innocent \& P.J. Masimba. 2009. Antimicrobial and cytotoxic activities of fresh leaf extracts of Warburgia ugandensis. Tanzania Journal of Health Research 11(2):75-78. dx.doi.org/10.4314/thrb. v11i2.45205

McMullin, S., J. Phelan, R. Jamnadass, M. liyama, S. Franzel \& M. Nieuwenhuis. 2012. Trade in medicinal tree and shrub products in three urban centres in Kenya. Forests, Trees and Livelihoods 21(3):188-206. dx.doi.org/10 $\underline{.1080 / 14728028.2012 .733559}$

Muchugi, A., G.M. Muluvi, R. Kindt, C.A.C. Kadu, A.J. Simons \& R.H. Jamnadass. 2008. Genetic structuring of important medicinal species of genus Warburgia as revealed by AFLP analysis. Trees Genetics and Genome 4(4):787795.

Muriuki, J., F. Franzel, J. Mowo, P. Kariuki \& R. Jamnadass. 2012. Formalisation of local herbal product markets has potential to stimulate cultivation of medicinal plants by smallholder farmers in Kenya. Forests, Trees and Livelihoods 21(2):114-127. dx.doi.org/10.1080/14728028.201 2.721959

Nanyingi, M.O., J.M. Mabaria, A.L. Lanyasunya, C.G. Wagate, K.B. Koros, H.F. Kaburia, R.W. Munenge \& W.O. Ogara. 2008. Ethnopharmacological survey of Samburu district, Kenya. Journal of Ethnobiology and Ethnomedicine 4:14. dx.doi.org/10.1186/1746-4269-4-14

Njoroge, G. 2012. Traditional medicinal plants in two urban areas in Kenya (Thika and Nairobi): Diversity of traded species and conservation concerns. Ethnobotany Research and Applications 9:329-338.

Ruiz-Pérez, M., B. Belcher, R. Achdiawan, M. Alexiades, C. Aubertin, J. Caballero, B. Campbell, C. Clement, T. Cunningham, A. Fantini, H. de Foresta, C. García Fernández, K.H. Gautam, P.H. Martínez, W. de Jong, K. Kusters, M.G. Kutty, C. López, M. Fu, M.A. Martínez Alfaro, T.K.R. Nair, O. Ndoye, R. Ocampo, N. Rai, M. Ricker, K. Schreckenberg, S. Shackleton, P. Shanley, T. Sunderland \& Y.-C. Youn. 2004. Markets drive the specialization strategies of forest peoples. Ecology and Society 9(2):4. www.ecologyandsociety.org/vol9/iss2/art4/

Schippmann, U., A.B. Cunningham \& D.J. Leaman. 2006. A comparison of cultivation and wild collection of medicinal and aromatic plants under sustainability aspects. Pp. 75-95 in Medicinal and Aromatic Plants: Agricultural, 


\section{McMullin et al. - Strategies for Sustainable Supply of and Trade in Threatened Medicinal Tree Species: A case study of genus Warburgia}

683

commercial, ecological, legal, pharmacological, and social aspects. Wageningen UR Frontis Series, Volume 17. Edited by R.J. Bogers, L.E. Craker \& D. Lange. Springer, Dordrecht, Netherlands.

Schippmann, U., D. Leaman \& C. Cunningham. 2002. Impact of cultivation and gathering of medicinal plants on biodiversity: Global trends and issues. Pp. 140-167 in Biodiversity and the Ecosystem Approach in Agriculture, Forestry, and Fisheries. Proceedings of a satellite event on the occasion of the Ninth Regular Session of the Commission on Genetic Resources for Food and Agriculture, Rome, Italy, 12-13 October 2002. Edited by FAO InterDepartmental Working Group on Biological Diversity for Food and Agriculture. Food and Agriculture Organization of the United Nations (FAO), Rome, Italy.
Sindiga, I., C. Nyaigotti-Chacha \& M.P. Kanunah. 1995 Traditional Medicine in Africa. East African Educational Publishers, Nairobi, Kenya.

Williams, V.L., E.T.F. Witkowski \& K. Balkwill. 2007. Volume and financial value of species traded in the medicinal plant markets of Gauteng, South Africa. International Journal of Sustainable Development and World Ecology 14(6):584-603. dx.doi.org/10.1080/13504500709469757

World Agroforestry Centre. 2011. Agroforestree Database. www.worldagroforestry.org/resources/databases/ agroforestree

XE. 2011. XE Universal Currency Converter. www.xe.com/ currencyconverter/ 
